\title{
土質力学に基づく土塗壁の耐力変形推定式の提案 \\ 一壁土のせん断破壊が卓越する場合 - \\ PROPOSAL OF MECHANICAL MODEL FOR ESTIMATION OF RELATIONSHIP \\ BETWEEN STRENGTH AND DEFORMATION OF MUD WALL \\ BASED ON SOIL MECHANICS \\ - In case of mud wall with initial failure in shear -
}

\author{
宇都宮 直樹*, 宮本 慎 宏**, 山中 稔***, 松島 学**** \\ Naoki UTSUNOMIYA, Mitsuhiro MIYAMOTO, Minoru YAMANAKA \\ and Manabu MATSUSHIMA
}

\begin{abstract}
In this paper, we propose the mechanical model of mud walls with initial failure in shear based on soil mechanics to estimate the relationship between strength and deformation. We also perform the full-scale static lateral loading tests of mud walls to grasp the fracture mode and the relationship between lateral loading and deformation. Finally, compared with the full-scale test results, the accuracy of estimation results is examined. From the results of these tests and estimations, it is found that the relationship between lateral loading and deformation of mud walls can be estimated with the mechanical model proposed in this paper.
\end{abstract}

Keywords : mud wall, soil mechanics, cohesion, angle of shear resistance, static loading test 土塗壁，土質力学，粘着力，せん断抵抗角，静的水平載荷実験

\section{1.はじめに}

土塗壁に用いられる壁土は，身近に採取できる粘性のある土と塗 り層に応じて中塗りすさや葍すさ等を混ぜ合わせたものである。土 とすさの調合は職人の経験と勘によって行われ，定量的な評価法に 基づく調合は行われていない。土塗壁を用いた建築物は壁土が有効 なせん断抵抗要素となるため, 壁土のせん断強度に影響を及ぼす粘 着力やせん断抵抗角などの強度定数を把握する必要がある。壁土の 強度特性は採取される地域やすさ混合量によって異なるため, 地域 ごとの土塗壁の耐力変形関係を把握するには，実大実験や部分壁体 実験を行う必要があり, 多くの時間と費用を要する。そこで，壁土 の要素実験から強度定数を把握し, 土塗壁の耐力変形関係を評価す ることが必要とされる。

土塗壁の抵抗機構の解明と力学モデルの構築に関する研究として 村上ら ${ }^{1) ~ 55) ~}$ は, 各種の土塗壁の水平加力実験に基づき, 水平力に対 する土塗壁の破壞性状と耐荷機構を解明している。部分壁体の要素 試験を行うことで様々な仕様の土叙壁の耐力変形関係を推定する方 法を提案している。中尾ら 6) 7) は, 壁土の各種材料試験結果から土 塗壁のせん断耐力の推定や数值解析による耐力変形関係の推定を行 っている。田淵ら ${ }^{8)}$ は, 京町家型の土塗壁の実大実験を行い, 材料
定数を用いて土塗壁の剛性及び耐力を推定する力学モデルを提案し ている。山田ら 9) 11)は，コンクリートの構成則をもとに土塗壁要素 を作成し, 壁長が $910 \mathrm{~mm}$ の土塗壁や小壁の耐力変位曲線の数值解 析が可能なことを示している。しかし, 既往の土塗壁の力学モデル に関する研究では, 壁土の圧縮強度と引張強度を用いて評価がなさ れており，土質力学に基づいて壁土のせん断強度に影響を及ぼす強 度定数を考慮した研究は行われていない。

本論文は土質力学に基づき, 壁土のせん断強度に影響を及ぼす強 度定数を要素実験から算定し，壁土のせん断破壊が卓越する土塗壁 の耐力低下域に至るまでの耐力変形関係の推定式を構築することを 目的とする。さらに，土塗壁の静的水平載荷実験を行い，提案した 耐力変形関係推定式の有効性を確認している。

\section{2.土塗壁の耐力変形推定式の提案}

\section{1 耐力変形推定フロー}

筆者らがこれまでに行った壁土に関する実験的研究において，土 質力学に基づいて葍すさを混合した壁土のせん断強度を強度指標で 示し 12), これまで要素実験で用いられてきた平板供試体よりも壁土 の強度定数を精度よく求めることができる円柱供試体を提案してい
* 四国職業能力開発大学校住居環境科 講師

** 香川大学工学部安全システム建設工学科 助教・博士 (工学)

*** 香川大学工学部安全システム建設工学科 准教授・博士 (工学)

**** 香川大学工学部安全システム建設工学科 教授・工博
Lecturer, Dept. of Residential Environment, Shikoku Polytechnic College Research Assoc., Dept. of Safety Systems Construction Eng., Univ. of Kagawa, Dr. Eng. Assoc. Prof., Dept. of Safety Systems Construction Eng., Univ. of Kagawa, Dr. Eng. Prof., Dept. of Safety Systems Construction Eng., Univ. of Kagawa, Dr. Eng. 
る ${ }^{13)}$ 。本論文ではこれらの既往の研究成果に基づき, 壁土のせん断 破壊が卓越する土塗壁の耐力変形関係の推定を図 1 に示すフローに 従って行う。本モデルは 1 間幅 $(1820 \mathrm{~mm})$ の土叙壁を対象とする。

図 1(a)に示すように壁土の一軸圧縮試験を行い, 応力度一ひずみ 度関係から弾性係数 $E_{50}$, 圧縮強さ $\sigma_{u}$ と要素実験のせん断破壊面の 角度 $\alpha_{f}$ から壁土の粘着力 $c$ とせん断抵抗角 $\phi$ を求める。次に, 土塗 壁の破壞モードを想定する。水平荷重を受ける土塗壁は軸組から拘 束力を受け, 拘束力の増加により図 $1(\mathrm{~b})$ に示す $\mathrm{A}$ 点および $\mathrm{D}$ 点の 隅角部から, それぞれ $\mathrm{B}$ 点および $\mathrm{C}$ 点に向けて壁土にせん断ひび割 れが生じ, 圧縮ストラットが形成される。荷重は圧縮ストラットに より伝達され, 圧縮ストラットの B-C 面がせん断破壊する時に最大 耐力となる。本推定式ではせん断面 B-C が保有する壁土のせん断耐 力を超えると土塗壁がせん断破壊すると仮定する。

提案する耐力変形角関係のモデルは図 1(c)に示すように, 降伏耐 力 $P_{y}$ の後, 最大耐力 $P_{u}$ となる 2 段階の剛性を持つと仮定している。

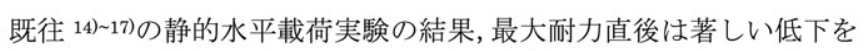
生じないことから, 最大耐力を保持する変形角 $\gamma_{u}{ }^{\prime}$ を考慮する。最大 耐力保持以降は変形の増加に伴う耐力低下をモデル化し, 要素実験 の応力度一ひずみ度関係を用いて連続的に土塗壁の耐力変形関係の 推定を行う。

\section{2 耐力の推定}

\section{2.1 壁土のせん断強度と強度定数の関係}

壁土のせん断強度 $\tau$ は, モール・クーロンの破壊基準から粘着力 $c$, せん断抵抗角 $\phi$ とせん断破壊面に垂直に作用する応力度 $\sigma$ を用い て式(1)のように示される。

$$
\tau=c+\sigma \cdot \tan \phi
$$

壁土の強度定数は図 1(a)に示すように, 中塗りすさを混合した壁 土の一軸圧縮試験を行い, 供試体の高さ方向に生じるせん断破壊面 の角度 $\alpha_{f}$ から求められる。せん断抵抗角 $\phi$ はモール・クーロンの破 壊基準より, せん断破壊面の角度 $\alpha_{f}$ を用いて式(2)で示され, せん断 抵抗角 $\phi$ が大きくなると破壊面の角度 $\alpha_{f}$ も大きくなる。

$$
\phi=2 \alpha_{f}-\frac{\pi}{2}
$$

壁土の圧縮強さを $\sigma_{u}$ とすると, モール・クーロンの破壊基準から 一軸圧縮試験では供試体に生ずる側圧が 0 のため, 粘着力 $c$ は式(3) で求めることができる。

$$
c=\frac{\sigma_{u} \cdot(\sec \phi-\tan \phi)}{2}
$$

\section{2.2 最大耐力 $P_{u}$ の推定}

図 2 に示すように土塗壁のせん断破壊時に抵抗する B-C 間の長さ
$L_{W}=H-L$ は, せん断ひび割れの角度 $\theta$ を $\pi / 4$, 水平力による拘束力 は柱から伝達されると仮定して算出している。本来は鉛直方向の拘 束力を考慮して圧縮ストラットの幅 $L_{V}$ を決定する必要があるが, 既 往 14) 17)の試験体のひび割れ発生状況からせん断破壊が生じた長さ が $L_{W}=H-L$ に概ね等しく, ひび割れ発生後の抵抗機構が簡潔に表 現できるため, せん断ひび割れ角度 $\theta$ を $\pi / 4$ とし, 水平力の釣り合 いのみを考慮した。せん断ひび割れは隅角部を支点として土塗壁中 央部に向かって生じるため, せん断ひび割れ角度 $\theta$ は試験体形状の 影響を受け, 壁土の強度定数による影響は小さいと考えられる。

$\mathrm{B}^{\prime}-\mathrm{C}$ 間の圧縮ストラットの幅 $L_{v}$ は $L_{v}=L_{w} \cdot \cos \theta$, 圧縮ストラット に沿って作用する力 $P_{v}$ とせん断破壊時の最大耐力 $P_{u}$ の関係は $P_{v}$ $=P_{u} \cdot \cos \theta$ となる。せん断力を負担する有効壁土厚さを $t_{w}$ とすると $\mathrm{B}^{\prime}-\mathrm{C}$ 面に作用する垂直応力度 $\sigma_{V}$ は式(4)となる。

$$
\sigma_{v}=\frac{P_{V}}{L_{v} \cdot t_{W}}=\frac{P_{u} \cdot \cos \theta}{L_{W} \cdot t_{W} \cdot \cos \theta}=\frac{P_{u}}{L_{w} \cdot t_{W}}
$$

さらに, B-C 面に作用する垂直応力度 $\sigma_{v}^{\prime}$ は式(5)となる。

$$
\sigma_{V}^{\prime}=\sigma_{v} \cdot \cos \theta=\frac{P_{u} \cdot \cos \theta}{L_{W} \cdot t_{W}}
$$

土塗壁のせん断破壊時の最大耐力 $P_{u}$ は, 有効壁土厚さ $t_{w}$ にせん 断抵抗する長さ $L_{w}$ と壁土内部に生じるせん断応力度 $\tau$ を乗じたもの であり，式(1)において $\sigma=\sigma_{v}{ }^{\prime}$ とすると式(6)となる。

$$
P_{u}=t_{W} \cdot L_{W} \cdot \tau=t_{W} \cdot(H-L) \cdot\left(c+\sigma_{V}{ }^{\prime} \cdot \tan \phi\right)
$$

式(6)に式(5)を代入し,$P_{u}$ について整理すると式(7)となる。式(2), (3)で求めた壁土の強度定数を代入することで最大耐力 $P_{u}$ を求める ことができる。

$$
P_{u}=\frac{c \cdot t_{W} \cdot(H-L)}{1-\cos \theta \cdot \tan \phi}
$$

ただし, $H-L>0, \theta=\pi / 4$ である。

有効壁土厚さ $t_{w}$, 粘着力 $c$, せん断抵抗角 $\phi$ が増加すると最大耐 力 $P_{u}$ も増加することがわかる。

\section{2.3 降伏耐力 $P_{y}$ の推定}

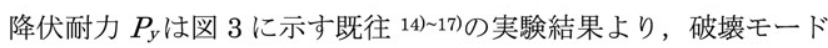
がせん断破壊となる試験体の最大耐力 $P_{u}$ に対する降伏耐力 $P_{y}$ の比 (以降, 耐力比と呼称する)の平均值が $P_{y} / P_{u} \cong 0.64$ であることから 式(8)とする。

$$
P_{y}=0.64 \cdot P_{u}
$$

\section{2.4 耐力低下域の耐力 $P_{r}$ の推定}

壁土の要素実験において, 圧縮強さ $\sigma_{u}$ 以降のモールの応力円は図 4 のように変化するため, 最大耐力後の耐力低下域での壁土の内部
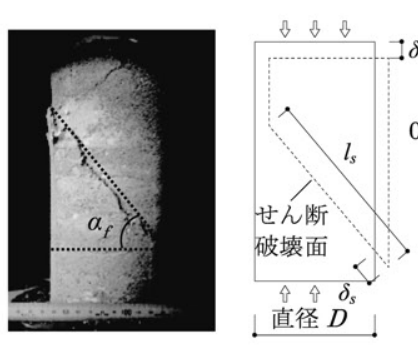

(a)壁土の一軸圧縮試験

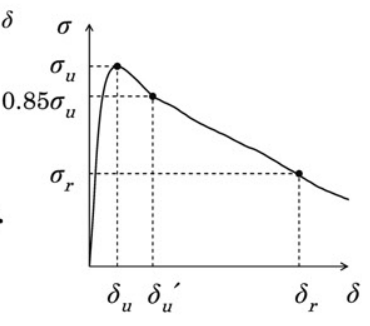

図 1 耐力変形推定フロー

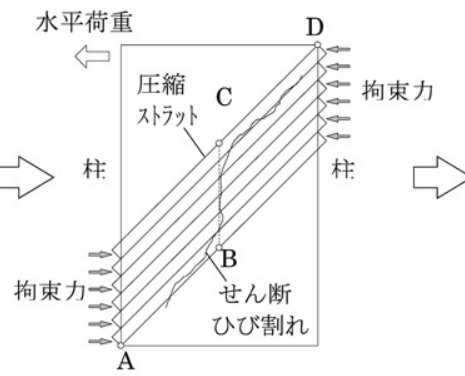

(b) 土塗壁の抵抗機構

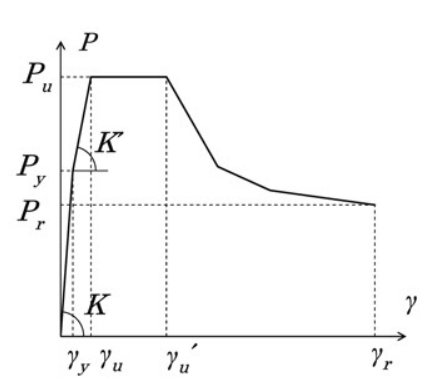

(c)耐力変形角関倸 
応力は小さくなる。クーロンの破壊線はモールの応力円と接するこ とから, 圧縮応力度 $\sigma$ すなわちせん断破壊面に作用する垂直応力度 $\sigma_{v}{ }^{\prime}$ の低下に伴いせん断応力度 $\tau$ も低下する。この耐力低下域の応力 度 $\sigma_{r}$ 時の粘着力を残留粘着力 $c^{\prime}$ とすると, モール・クーロンの破壊 基準から式(9)となる。

$$
c^{\prime}=\frac{\sigma_{r} \cdot(\sec \phi-\tan \phi)}{2}
$$

式(7)において $c=c^{\prime}$ として式(9)に代入すると式(10)となり, 図 1(c) に示す最大耐力後の耐力低下域の耐力 $P_{r}$ を求めることができる。

$$
P_{r}=\frac{c^{\prime} \cdot t_{W} \cdot(H-L)}{1-\cos \theta \cdot \tan \phi}
$$

\section{3 変形角の推定}

\section{3. 1 降伏変形角 $\gamma_{y}$ の推定}

土塗壁の弾性域において, 壁土内部に生じるせん断応力 $\tau_{1}$ とせん 断弾性係数 $G$, せん断変形角 $\gamma$ の関係は $\tau_{1}=G \cdot \gamma$ である。せん断弾性 係数 $G$ は土質力学に基づき壁土の弾性係数 $E_{50}$, ポアソン比 $v$ より 式(11)で示され,これらの関係からせん断応力度 $\tau_{1}$ は式(12) となる。

$$
\begin{gathered}
G=\frac{E_{50}}{2 \cdot(1+v)} \\
\tau_{1}=\frac{E_{50} \cdot \gamma}{2 \cdot(1+v)}
\end{gathered}
$$

ここで壁土のポアソン比 $v$ を 0.2 とする。壁土の弾性係数 $E_{50}$ は 文献 19)に基づき圧縮強さ $\sigma_{u}$ の $1 / 2$ と原点を結ぶ直線の傾きとする。 水平荷重 $P$ と壁土内部に生じる平均せん断応力度 $\tau_{2}$ の関係は, せ ん断面積 $A$ を有効壁土厚さ $t_{w}$ と内法長さ $L$ を乗じた $A=t_{w} \cdot L$ とす ると式(13)となる。

$$
\tau_{2}=\frac{P}{t_{w} \cdot L}
$$

$\tau_{1}=\tau_{2}$ であることからせん断変形角 $\gamma$ について整理すると式(14) となり降伏変形角 $\gamma_{y}$ を求めることができる。

$$
\gamma_{y}=\frac{2 \cdot P_{y} \cdot(1+v)}{t_{W} \cdot L \cdot E_{50}}
$$

\section{3. 2 最大耐力時の変形角 $\gamma_{u}$ の推定}

初期剛性 $K$ に対する降伏耐力 $P_{y}$ から最大耐力 $P_{u}$ までの第 2 剛性 $K^{\prime}$ の比(以降, 剛性比とする)は, 図 3 に示す既往の実験結果 14) 17) の平均值から $K^{\prime} \mid K \cong 0.38$ とする。最大耐力時の変形角 $\gamma_{u}$ は, 降伏 変形角 $\gamma_{y}$ を用いて式(15)と示すことができる。

$$
\gamma_{u}=\frac{\left(P_{u}-P_{y}\right)}{K^{\prime}}+\gamma_{y}
$$

\section{3. 3 最大耐力を保持する変形角 $\gamma_{u}^{\prime}$ の推定}

要素実験において圧縮強さ $\sigma_{u}$ 以降は, 図 $1(\mathrm{a})$ に示すようなせん断 変形を示す。この時のせん断破壊面の長さ $l_{s}$ に対するせん断ひずみ $\delta_{s}$ の比をせん断ひずみ度 $\gamma_{s}$ とする。せん断破壊面の長さ $l_{s}$ は円柱供 試体の直径 $D$ と破壊面の角度 $\alpha_{f}$ から $D / \cos \alpha_{\mathrm{f}}$ であり，せん断ひずみ $\delta_{s}$ は鉛直変位 $\delta$ と破壊面の角度 $\alpha_{f}$ から $\delta / \sin \alpha_{f}$ となる。これらの関係 からせん断ひずみ度 $\gamma_{s}$ は式(16)で表される。ここで, 破壊面の角度 $\alpha_{f}$ は土塗壁の圧縮ストラットの角度 $\theta$ を考慮し $\pi / 4$ とする。

$$
\gamma_{s}=\frac{\delta_{s}}{l_{s}}=\frac{\delta \cdot \cos \alpha_{f}}{D \cdot \sin \alpha_{f}}=\frac{\delta}{D \cdot \tan \alpha_{f}}=\frac{\delta}{D}
$$

最大耐力以降の土塗壁の変形は, 弾性変形していた壁土が圧縮ス トラットのせん断破壊によって塑性化してひずみの局所化が起こり, 塑性変形によって全体変形が支配されると仮定する。よって最大耐 力以降の変形角 $\gamma_{r}$ は, 式(15)で求めた最大耐力時の変形角 $\gamma_{u}$ に式(16) で求めた要素実験時の圧縮強さ $\sigma_{u}$ 以降のせん断ひずみ度 $\gamma_{s}$ を加算し て求める。既往 14) 17)の静的水平載荷実験の最大耐力後の耐力変形関 係は 1/50rad まで著しい耐力低下を生じないことから, 図 1(a)に示 す要素実験において圧縮強さ $\sigma_{u}$ の $85 \%$ に低下寸るまでの鉛直変位 $\delta_{u}{ }^{\prime}$ に相当するせん断ひずみ度を図 1 (c)に示す最大耐力を保持する変 形角 $\gamma_{u}{ }^{\prime}$ とする。よって最大耐力を保持する土塗壁の変形角 $\gamma_{u}{ }^{\prime}$ は, 式(16)より圧縮強さ $0.85 \sigma_{u}$ 時の鉛直変位 $\delta_{u}{ }^{\prime}$ と圧縮強さ時の鉛直変 位 $\delta_{u}$ 間のせん断ひずみ度を求め, 式(15)で求めた最大耐力時の変形 角 $\gamma_{u}$ を用いて式(17)で表される。

$$
\gamma_{u}^{\prime}=\frac{\delta_{u}^{\prime}-\delta_{u}}{D}+\gamma_{u}
$$

\section{3. 4 耐力低下域の変形角 $\gamma_{r}$ の推定}

耐力低下域において, 最大耐力時に図 1(b)の A-B-C-D 面内に生じ た壁土のせん断ひび割れが頂部の変形の進行に合わせて拡大および 連結し，大きなひび割れ面を形成する。土塗壁の耐力低下域のせん 断変形角 $\gamma_{r}$ は, 式(16)より圧縮強さ以降の鉛直変位 $\delta_{r}$ と圧縮強さ時 の鈆直変位 $\delta_{u}$ 間のせん断ひずみ度を求め, 式(15)で求めた最大耐力 時の変形角 $\gamma_{u}$ を用いて式(18)で表される。

$$
\gamma_{r}=\frac{\delta_{r}-\delta_{u}}{D}+\gamma_{u}
$$

以上より, 要素実験より求めた壁土の強度定数から図 $1(\mathrm{c})$ に示す 最大耐力後の耐力低下域に至るまでの土塗壁の耐力変形関係が推定 できる。

\section{3. 土塗壁の静的水平載荷実験}

文献 18)では, 中塗り仕上げの土塗壁に作用するせん断力の大部 分は中塗りおよび中付け(本論文では大直し塗りに相当する)で負担 するとされている。そこで本実験では, 中塗りすさ混合量と中塗り 厚さをパラメータとして土塗壁の静的水平載荷実験を行い, 荷重変 形関係や破壊モードの把握を行う。

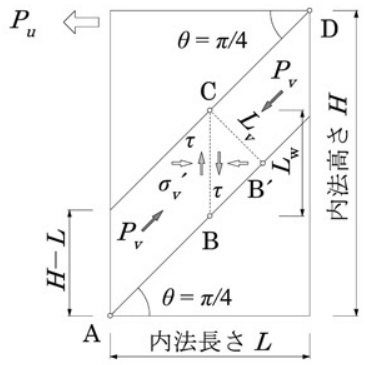

図 2 せん断破壊時の内部応力

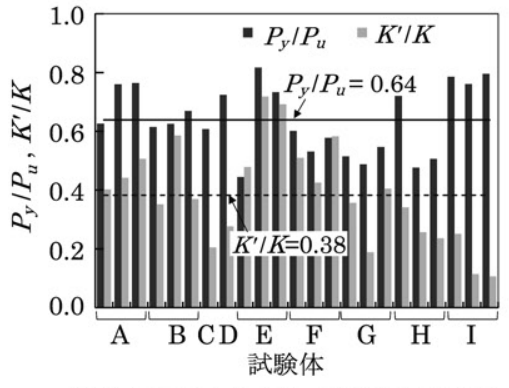

図 3 耐力比 $P_{y} / P_{u}$, 剛性比 $K^{\prime} / K$

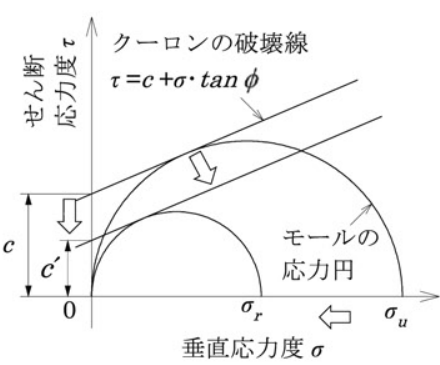

図 4 最大耐力後の粘着力の推移 


\section{1 壁土の要素実験}

荒壁土，裏返し土および大直し土は香川県内で産出され，壁土製 造業者によって製造されたものを用いた。壁土の練り置きは行わな かった。中塗り土はおろし土を使用し, おろし土と砂の調合は質量 比で $1: 2$ であった。中塗りすさ混合量は左官技能者に中塗りとし て施工可能な混合量の範囲内で少量と多量の 2 水準で調合を行って もらった。調合時に少量, 多量で混合したすさ量は, それぞれおろ し土 100 リットルに対し $1.1 \mathrm{~kg}$ と $1.9 \mathrm{~kg}$ であった。供試体の作製は すさを混合した壁塗り直前の状態の各壁土を直径 $125 \mathrm{~mm}$, 高さ $250 \mathrm{~mm}$ の円筒形型枠に入れて成型し, 2 週間程度の気中養生を行っ た。脱型後, 質量変化が低下するまで気中養生を行った。壁土の試 験条件を一定にするために試験前に温度 $20^{\circ} \mathrm{C}$, 湿度 $60 \%$ の恒温恒 湿器内で 24 時間養生して実験を行った。実験時の壁土の含水比は 1.2 2.3\%であった。試験体数は各 5 体とした。要素実験は文献 19) に準じて圧縮試験を行い, 毎分 $1 \%$ の圧縮ひずみが生じる割合で加 力を行った。実験後, 壁土強度定数の評価法 13)に基づき粘着力 $c$, せん断抵抗角 $\phi$, 弾性係数 $E_{50}$ の算定を行った。

表 1 に要素実験で得られた各壁土の圧縮強さ $\sigma_{u}$, 弾性係数 $E_{50}$, 粘着力 $c$, せん断抵抗角 $\phi$ および推定せん断強度 $\tau$ の平均值, 図 5 に各壁土の圧縮応力度-ひずみ度関係の平均值を示す。中塗りすさ混 合量を 1.7 倍に増加させると, 圧縮強さ $\sigma_{u}$, 弾性係数 $E_{50}$ は 0.9 倍 となり, 本実験の範囲における中塗りすさ混合量の増加が壁土の強 度特性一及ぼす影響は小さかった。これは中塗りすさの形状が厚さ 0.1 0.3mm, 幅 $1 \mathrm{~mm}$ と偏平であるため, 土塗壁の土粒子の体積の 減少が抑えられ，土粒子間の結合が低下しなかったことが要因と考 えられる。また, 図 5 に示すように圧縮強さ $\sigma_{u}$ 後の強度低下は, 緎 維補強効果により中塗りすさ混合量が多くなると緩やかになった。

\section{2 実大試験体概要}

試験体は図 6 に示す長さ $1820 \mathrm{~mm}$ の土塗壁とした。材種は貫, 柱, 横架材および土台に杉を用いた。部材寸法は柱および土台は 105

表 1 要素実験結果 (5 体平均)

\begin{tabular}{|c|c|c|c|c|c|c|}
\hline $\begin{array}{l}\text { 壁土 } \\
\text { 種類 }\end{array}$ & 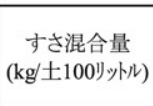 & $\begin{array}{c}\text { 圧縮強さ } \\
\sigma_{u} \\
\left(\mathrm{~N} / \mathrm{mm}^{2}\right)\end{array}$ & $\begin{array}{c}\text { 弾性係数 } \\
E_{50} \\
\left(\mathrm{~N} / \mathrm{mm}^{2}\right)\end{array}$ & $\begin{array}{c}\text { 粘着力 } \\
c \\
\left(\mathrm{~N} / \mathrm{mm}^{2}\right)\end{array}$ & $\begin{array}{c}\text { せん断 } \\
\text { 抵抗角 } \phi \\
\left({ }^{\circ}\right)\end{array}$ & $\begin{array}{c}\text { 推定せん断 } \\
\text { 強度 } \tau \\
\left(\mathrm{N} / \mathrm{mm}^{2}\right)\end{array}$ \\
\hline 荒壁土 & 1.8 & 0.58 & 90.4 & 0.24 & 12 & 0.28 \\
\hline $\begin{array}{l}\text { 裏返し土 } \\
\text { 大直し土 }\end{array}$ & 2.0 & 0.72 & 126.6 & 0.32 & 7 & 0.36 \\
\hline $\begin{array}{l}\text { 中塗り土 } \\
\text { すさ少 }\end{array}$ & 1.1 & 0.97 & 251.7 & 0.37 & 16 & 0.46 \\
\hline $\begin{array}{l}\text { 中塗り土 } \\
\text { すさ多 }\end{array}$ & 1.9 & 0.84 & 226.9 & 0.36 & 9 & 0.42 \\
\hline
\end{tabular}

表 2 各試験体の壁土塗り厚さ

\begin{tabular}{|c|c|c|c|c|c|}
\hline \multirow{2}{*}{ 試験体名 } & \multirow{2}{*}{$\begin{array}{l}\text { 裹:裏返し } \\
\text { (mm) }\end{array}$} & \multirow{2}{*}{$\begin{array}{c}\text { 太: 大直し } \\
(\mathrm{mm})\end{array}$} & \multirow{2}{*}{$\begin{array}{c}\text { 里: 中塗り } \\
(\mathrm{mm})\end{array}$} & \multicolumn{2}{|c|}{$\begin{array}{c}\text { 有効壁土厚さ } \\
t_{\mathrm{w}}(\mathrm{mm})\end{array}$} \\
\hline & & & & \begin{tabular}{|c|} 
上限値 \\
裏+大+中
\end{tabular} & $\begin{array}{l}\text { 下限值 } \\
\text { 大+虫 }\end{array}$ \\
\hline 薄塗-すさ少 & 15 & 14 & 7 & 36 & 21 \\
\hline 薄塗-すさ多 & 15 & 16 & 6 & 36 & 22 \\
\hline 厚塗-すさ少 & 15 & 15 & 16 & 46 & 31 \\
\hline 厚塗-すさ多 & 13 & 16 & 15 & 44 & 31 \\
\hline
\end{tabular}

試験体の凡例を以下に示す。

薄塗一すさ少— 中叙りすさ混合量

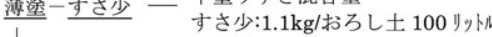

中叙り厚さすさ多: $1.9 \mathrm{~kg} /$ おろし土 100 リット

薄塗: $6 \mathrm{~mm}$ 程度, 厚塗: $15 \mathrm{~mm}$ 程度 ×105mm，横架材は $105 \times 180 \mathrm{~mm}$ ，貫は $15 \times 105 \mathrm{~mm}$ とした。柱と 貫の仕口は大入れとし，楔で留めた。柱間の中央には縦貫を配して いる。壁土を塗付ける下地は端部の直径が $15 \mathrm{~mm}$ 程度の丸竹, 小舞 に幅 $22 \mathrm{~mm}$ 程度の割竹を使用した。本実験における柱と土台および 横架材の仕口は，接合部のモーメント抵抗の影響を除去し，できる だけ壁土の影響のみを確認できるように, 抵抗方向にそれぞれ $5 \mathrm{~mm}$ のクリアランスを設け, 直径 $15 \mathrm{~mm}$ の込み栓で接合した。施工は小 舞择きを行った後に荒壁塗りを行い，乾燥収縮に伴うひび割れが終 了してから裏返し塗り, 大直し塗りを行い, 中塗りを片面塗りとし た。貫の位置に壁土のひび割れ抑制のために, 長さ $30 \mathrm{~cm}$ 程度の稲 㩰で貫伏せを行った。試験体は中塗りすさの混合量と中塗り厚さを 変えた 4 種類とした。表 2 に各試験体を実測して得られた壁土の塗 り厚さを示す。試験体数は各 1 体である。静的水平載荷実験時の壁 土の含水比は $0.9 \sim 2.3 \%$ あった。

\section{3 載荷および計測方法}

図 6 に載荷装置の概略図を示す。試験体の土台をM16 のアンカー ボルトで固定した後, 横架材にサーボアクチュエータを介して水平 荷重を与えた。載荷方法はタイロッド方式とし, 加力サイクルは文 献 20)を基に, 真のせん断変形角 $\gamma_{0}$ が 1/600,1/450,1/300,1/200,1/15 0,1/100,1/75,1/50rad で繰り返し，履歴の同一変形段階で 3 回の正 負交番繰り返し加力とした。終局は 1/10 rad までの片引きとした。 試験体に作用する荷重はサーボアクチュエータの先端に取り付けた ロードセルで計測した。変位の計測は変位計 $\mathrm{H} 1$ で横架材の水平方 向変位, $\mathrm{H} 2$ で土台の水平方向変位, 変位計 V3, V4 で柱の脚部の 鉛直方向変位の計測を行った。

\section{4 荷重変形角関係}

実大実験で得られた 4 体の実験結果を表 3 , 荷重変形角関係を図 7 に示す。初期剛性 $K_{e}$ は文献 20 )に基づいて算定した降伏耐力 $P_{y}$ と 原点を結ぶ直線の傾きとした。最大荷重となる変形角 $\gamma_{u}$ は, 中塗り

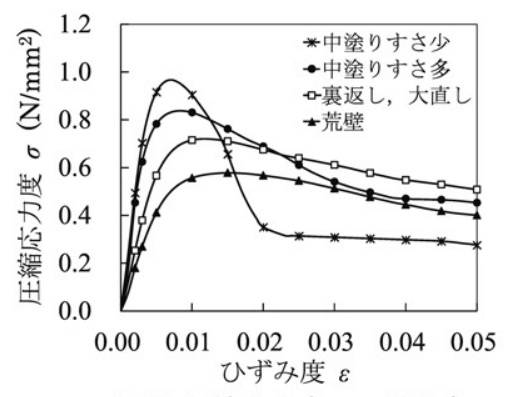

図 5 圧縮応力度一ひずみ度

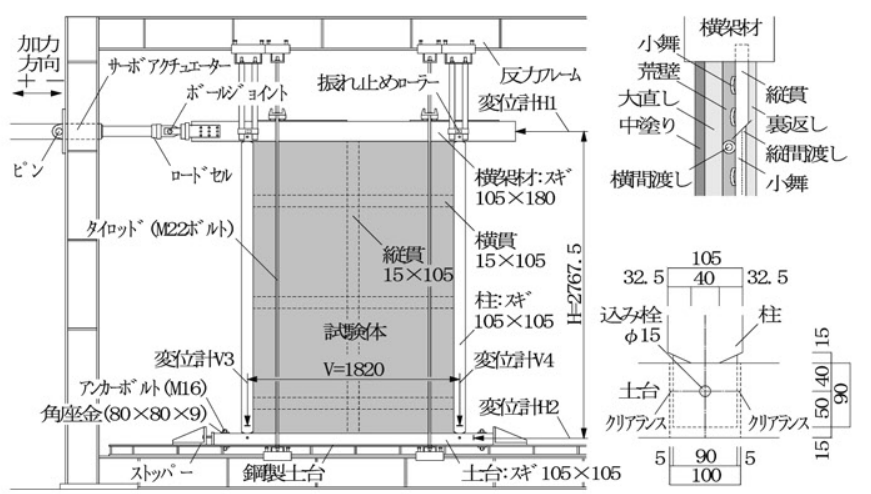

図 6 試験体形状および載荷装置 
が厚塗りの試験体で 1/100rad, 薄塗りの試験体で $1 / 75 \sim 1 / 50 \mathrm{rad}$ で あった。各試験体とも概ね 1/50rad までは最大荷重を保持する傾向 にあった。中塗りすさ混合量が多くなると, すさの繊維補強効果に より図 5 に示す要素実験時の圧縮強さ $\sigma_{u}$ 以降の強度低下が緩やかに なることから, 図 7 に示す土塗壁の荷重低下も緩やかになる傾向が 見られた。薄塗試験体に比べて厚塗試験体の最大荷重は,「すさ少」 で 1.3 倍, 「すさ多」で 1.4 倍, 初期剛性は「すさ少」で 1.2 倍, 「す さ多」で 1.5 倍の増加を示した。これは小舞下地と裏返し塗りの厚 さを除く壁土の断面積が 1.4 倍に増加したことが要因と考えられる。 中塗りすさの混合量が土塗壁の最大荷重に及ぼす影響は小さい。 中塗りすさは断面形状が偏平であり混合量が増加しても土塗壁内の 体積増加は少ないため, 著しく土粒子の体積が低下しない。本実験 の範囲では表 1 に示すように, すさ混合量を 1.7 倍に増加させても 壁土のせん断強度の低下は $9 \%$ 程度であり, これが明確な耐力差に ならなかった要因と考えられる。

中塗りすさ混合量の増加により, 初期剛性は厚塗試験体で 0.9 倍, 薄塗試験体では 0.7 倍に低下した。これは厚塗試験体の中塗り厚さ と中塗りの下層にある大直し塗り厚さが同程度であるため要素実験 結果と同様の傾向を示したと考えられる。また, 薄塗試験体では中 塗り厚さが 6 7mm に対して大直し塗り層の厚さが 14 16mm と厚 いため, 大直し土の弾性係数の影響を受けて低下したものと考えら れる。

\section{5 破壊性状}

実大実験における破壊過程を図 8 に示す。試験体種類による差異 は無く, 1/450radに横架材や土台と柱の隅角部で壁土の圧壊が生じ た。実験前には裏返し塗り側の横架材, 土台や壁土の境界部分には $5 \mathrm{~mm}$ 程度の乾燥収縮による隙間があるが，1/200 1/150 rad の変形 角でその隙間は無くなった。隅角部の圧壊は変形の増加により 1/150rad で縦貫付近まで進展するが，このひび割れによる耐力低下 は見られなかった。1/100rad 近傍で中塗り面側の隅角部付近から目 視で確認できる小さなせん断ひび割れが生じ, 変形が進行すると土 塗壁中央部に向けてせん断ひび割れが連結しながら進展した。 1/75rad では塗り厚さの薄い横貫部分に沿ったひび割れ，裏返し塗 り側では縌間渡し竹や縦貫に沿ったひび割れが生じ, 変形の進行に

表 3 実験結果と推定最大耐力

\begin{tabular}{|c|c|c|c|c|c|}
\hline \multirow[t]{2}{*}{ 試験体名 } & \multirow{2}{*}{\begin{tabular}{|c} 
最大荷重 \\
$P_{e u}$ \\
$(\mathrm{kN})$ \\
\end{tabular}} & \multirow{2}{*}{\begin{tabular}{|c|} 
最大荷重時 \\
の変形角 $\gamma_{u}$ \\
$(\mathrm{rad})$ \\
\end{tabular}} & \multirow{2}{*}{ 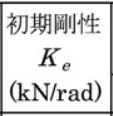 } & \multicolumn{2}{|c|}{\begin{tabular}{|c|} 
推定最大耐力 \\
$P_{c u}(\mathrm{kN})$ \\
\end{tabular}} \\
\hline & & & & \begin{tabular}{|c|} 
上限値 \\
\end{tabular} & 下限值 \\
\hline 溥型 & 10.80 & 0.013 & 1650 & 15.17 & 9.01 \\
\hline 潈 & .6 & 0.020 & 119 & 13.42 & 8.04 \\
\hline 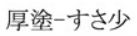 & .00 & 0.01 & 2059 & 19.25 & 12.97 \\
\hline 厚塗-すさ多 & 14.35 & 0.010 & 1777 & \begin{tabular}{|l|}
16.32 \\
\end{tabular} & 11.4 \\
\hline
\end{tabular}

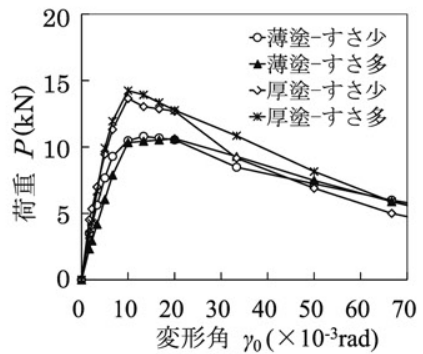

図 7 荷重変形角関係

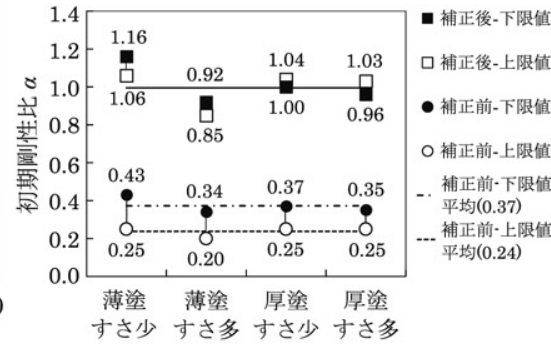

図 9 初期剛性の比較
伴ってひび割れの進展が観察された。土塗壁中央部の壁土にせん断 ひび割れが生じる $1 / 100 ~ 1 / 50 \mathrm{rad}$ で最大荷重となった。この時の土 塗壁中央部の破壊面は壁土が盛り上がった形跡が確認され，圧縮せ ん断であったことを示している。実験後のせん断破壊が生じた壁土 の断面は, 中塗りと大直し塗りが一体となった破壊モードを示した。

以上より, 静的水平載荷実験における実大試験体の破壊モードは, 図 8 に示すように軸組による隅角部の拘束，隅角部の壁土圧壊，土 塗壁中央部の壁土のせん断ひび割れとなり，図 1(b)で示した破壊モ ードと一致した。

\section{4. 実大実験結果と耐力変形推定值の比較}

提案した耐力変形関係の推定式の有効性を検討するため, 実大実 験結果との比較を行う。文献 18) より水平荷重の大部分は中付け(本 論文では大直し塗りに相当する)および中塗り層で負担されるため, 本論文ではせん断力を負担する有効壁土厚さ $t_{w}$ を, 貫及び小舞下地 の厚さ $30 \mathrm{~mm}$ を除いた厚さとする。耐力推定において有効壁土厚さ $t_{w}$ が及ぼす影響を把握するため, 土塗壁の壁土の構成を表 2 に示す 「中塗り+大直し」と「中塗り+大直し+裏返し」の 2 種類を考え, それ ぞれの推定值の下限值と上限值として耐力変形関係の推定を行う。

\section{1 初期剛性の比較}

推定值の初期剛性 $K_{c}$ は降伏耐力 $P_{y}$ と原点を結ぶ直線の傾きとし, $K_{c}$ に対する実験值の初期剛性 $K_{e}$ の比を初期剛性比 $\alpha$ とし, 図 9 に 示す。初期剛性比 $\alpha$ の平均值は推定值の上限值を用いた場合で 0.24 , 下限値を用いた場合で 0.37 となり, 推定值に対して実験值が低いこ とを示している。これは, 裏返し塗り等の下塗り層において, 壁土 の乾燥収縮に伴うひび割れや壁土と軸組の間に隙間が生じており, 閉口するまでは壁土による抵抗が有効に作用しないために初期剛性 $K_{e}$ が低下寸ることや, 文献 19)において要素実験の弾性係数 $E_{50}$ は 初期スリップを除いて評価を行うために推定值の初期剛性 $K_{c}$ が高 くなることが要因として考えられる。初期スリップが徐々に弾性時 の変形に影響していることは, 弾性載荷時に試験体の隙間等が徐々 に無くなっていることからも明らかである。そこで初期剛性の補正 が必要と考え, 図 9 に示寸初期剛性比 $\alpha$ の推定値の上限值および下 限值の平均值を壁土の弾性係数 $E_{50}$ に乗じて式(14)の降伏変形角 $\gamma_{y}$ の算定を行う。その結果, 図 9 に示寸ように補正後の初期剛性比は, 概ね実験結果と近い值になっている。

\section{2 耐力変形関係の比較}

2 章で提案した式によって推定した土塗壁の耐力変形関係と実験 結果の比較を図 10 に示す。最大耐力後の耐力低下域に至るまで推 定上限值と下限值間に実験值の包絡線が存在しており，実験結果を

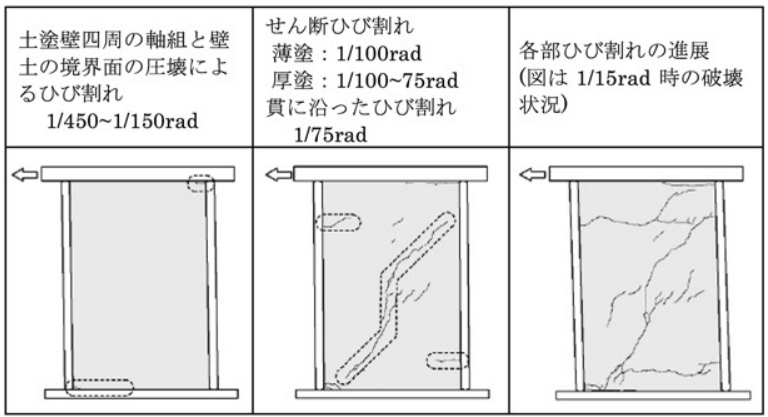

図 8 破壊過程 
概ね再現できている。推定值の $1 / 10 \mathrm{rad}$ は式(16)から要素実験にお けるひずみ 5.0 5.7\%に相当する。表 3 に示すように推定した最大 耐力は, 中塗り厚さが $6 \mathrm{~mm}$ から $15 \mathrm{~mm}$ となると, 下塗りを含めた 塗り厚さが上限值の「中塗り+裏返し+大直し」で 1.2 1.3 倍, 下限 值の「中塗り+大直し」で 1.4 倍に増加する。最大耐力について実験 值 $P_{e u}$ に対する推定值 $P_{c u}$ の割合を図 11 に示す。上限值は実験值の 1.14 1.41 倍, 下限值は $0.76 \sim 0.95$ 倍の範囲であり, 最大耐力が 推定範囲内にあることが確認できる。

以上より, 提案した耐力変形関係の推定式の有効性が示された。 本論文で提案した推定式を用いて, 中塗りを片面塗りとした壁土の せん断破壊が卓越する土塗壁の耐力変形関係を推定する場合, 中塗 り土の要素実験結果を用いて強度定数を求め, 壁土厚さは安全側を 考慮して下限值である「中塗り+大直し塗り」を設計式として提案 する。

\section{5. まとめ}

本論文では, 壁土の要素実験から得られた強度定数を用いて, せ ん断破壊が卓越する土塗壁の耐力変形関係の推定式を提案した。さ らに, 中塗りのすさ混合量と塗り厚さを変えた土塗壁の静的水平載 荷実験を行い, 耐力変形関係と破壊モードの把握を行った。推定値 と実験值の比較を行い, 提案した推定式の有効性を検証した。得ら れた知見を以下に示す。

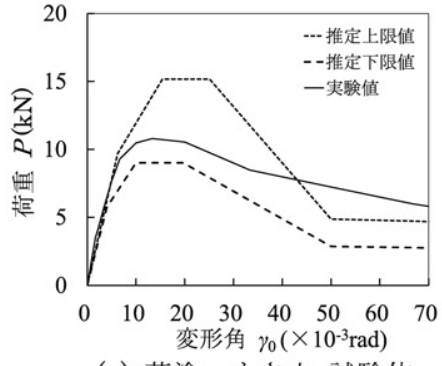

（a）薄塗一すさ少 試験体

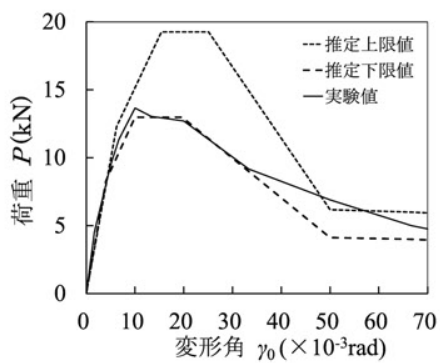

(c) 厚塗一すさ少 試験体

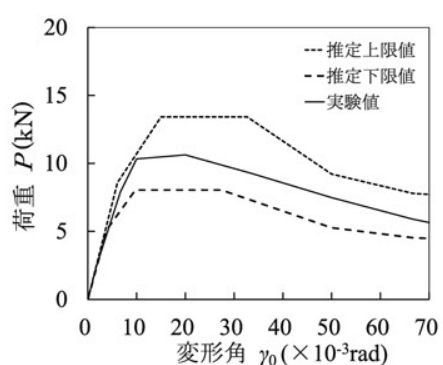

(b) 薄塗一すさ多 試験体

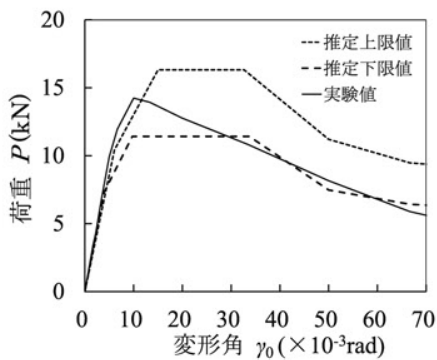

(d) 厚塗一すさ多 試験体
図 10 実験值と推定值の比較

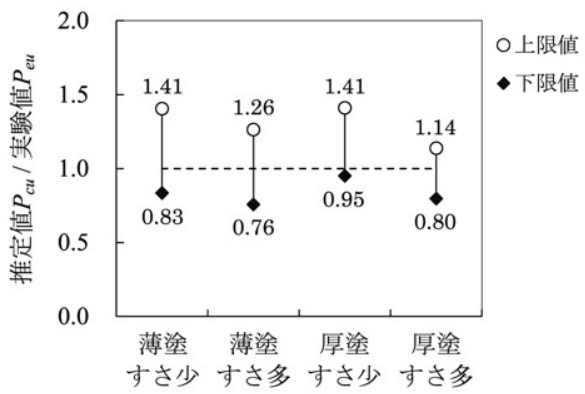

図 11 最大耐力における推定值 $P_{c u}$ /実験值 $P_{e u}$ の比較
1)壁土の要素実験結果から最大耐力後の耐力低下域に至るまでの 土塗壁の耐力変形関係の推定式を提案した。

2)静的水平載荷実験における試験体の破壊モードは, 壁土の隅角 部にせん断ひび割れが生じ, 十分な塑性変形後に端部から対角 線上に形成された圧縮ストラットの中央部がせん断破壊し, 推 定式で想定した破壊モードと一致することが確認された。最大 耐力はこの圧縮ストラットがせん断破壊することで決定された。 3)土塗壁の耐力は壁土厚さによって異なるため, 「中塗り+大直し 塗り」の厚さで推定した下限值と,「中塗り+大直し塗り+裏返し 塗り」の厚さで推定した上限值で推定式の有効性の検討を行っ た。その結果，推定した耐力変形関係の上限值と下限值の間に 概ね実験值の包絡線が存在しており，提案した推定式の有効性 を確認することが出来た。壁土厚さは安全側を考慮して下限值 である「中塗り+大直し塗り」を設計式として提案する。

\section{参考文献}

1）村上雅英，景山誠，鈴木有，稲山正弘：静的水平加力実験に基づく土壁の 耐荷機構の解明-せん断破壞が先行しない土壁の力学挙動-, 日本建築学会 構造系論文集，第 582 号, pp.103-108，2004.8

2）村上雅英，景山誠，鈴木有，稲山正弘：静的水平加力実験に基づく土壁の 耐荷機構の解明-せん断破壊が先行しない土壁の力学挙動(続)-, 日本建築 学会構造系論文集，第 594 号, pp.111-118, 2005.8

3）村上雅英, 景山誠, 岡本滋史, 鈴木有, 稲山正弘 : 水平力の耐荷機構に基 づく土壁の剛性と耐力の算定法に関する提案と検証, 日本建築学会構造系 論文集，第 605 号，pp.119-126，2006.7

4）岡本滋史，澤田圭，村上雅英，鈴木有，稲山正弘 : 部分壁体試験に基づく 土壁のせん断力-変形角関係及び壁倍率の推定方法と検証, 日本建築学会 構造系論文集，第 621 号，pp.103-110，2007.11

5）岡本滋史, 村上雅英, 稲山正弘 : 仕様の相違が土壁の構造性能に及ぼす影 響に関する実験的調查, 日本建築学会構造系論文集, 第 641 号, pp.1275-1283, 2009.7

6）中尾方人，一文字里紗，山崎裕，石橋庸子：土塗壁のせん断抵抗機構およ びせん断耐力の評価法に関する実験的研究，日本建築学会構造系論文集， 第 598 号, pp109-116, 2005.12

7) 中尾方人, 山崎裕 : 数值解析による土塗り壁のせん断抵抗機構の検討, 日 本建築学会構造系論文集，第 636 号, pp331-338, 2009.2

8）田淵敦士, 北守顕久, 森拓郎, 小松幸平: 京町家型土壁の水平せん断性能, 日本建筑学会構造系論文集, 第 605 号, pp143-150, 2006.7

9）山田耕司：土壁耐力の数値解析手法の開発，日本建築学会技術報告集，第 23 号, pp161-164, 2006.6

10) 山田耕司 : 壁土強度のばらつきの土壁耐力への影響, 日本建築学会構造系 論文集, 第 620 号, pp87-92, 2007.10

11)山田耕司，清水秀丸，中治弘行，鈴木祥之：土塗り小壁付き木造軸組耐力 特性評価一の数値解析の適用, 日本建築学会構造系論文集, 第 621 号, pp81-87, 2007.11

12) 宇都宮直樹, 松島学: 㩰スサを混合した壁士の力学的性質に関する実験的 研究, 日本建築学会構造系論文集, 第 649 号, pp.593-599, 2010.3

13) 宇都宮直樹, 山中稔, 松島学 : 菜スサを混合した新しい供試体の提案, 日 本建築学会構造系論文集，第 664 号，pp.1119-1124，2011.6

14)土壁ネットワーク：土壁の耐震性向上のための技術的研究 $2006 \cdot 2007$. 2008 年度報告書, 2009.3

15) 中尾裕典, 今西達也, 完山利行, 大西泰弘, 宇都宮直樹 : 小舞下地の仕様 の違いが土塗壁の耐力に及ぼす影響についてその 1 試験体の概要, 日本 建築学会大会学術講演梗概集, C-1, pp.347-348, 2010.9

16）今西達也, 中尾裕典, 完山利行, 大西泰弘, 宇都宮直樹 : 小舞下地の仕 様の違いが土塗壁の耐力に及ぼす影響についてその 2 面内せん断試験, 日本建築学会大会学術講演梗概集，C-1，pp.349-350，2010.9

17) 宇都宮直樹,宮本慎宏,山中稔,松島学, 大橋好光: 下地構成材の仕様が土塗壁 の耐震性能に及ぼす影響，構造工学論文集 vol.58B，pp.287-292，2012.3

18) 中尾方人, 山崎裕, 田中純 : 土塗り壁のせん断耐力の評価に関する実験的 研究, 構造工学論文集 vol.49B, pp.573-578, 2003.3

19)土の一軸圧縮試験法, JIS A $1216: 2009$

20)技術解説書作成編集委員会: 土塗壁·面格子壁·落とし込み板壁の壁倍率に 倸る技術解説書,pp.25,83-91,pp144-147, 日本住宅・木材技術センタ $-, 2004.2$ 